\title{
Piloting moringa agribusiness to improve villagers' economic community
}

\author{
Oki Wijaya ${ }^{\mathrm{a}, 1^{*}}$, Lestari Rahayu ${ }^{\mathrm{a}, 2}$, Nur Rokhim ${ }^{\mathrm{b}, 3}$, Tsaniya Yusmiastuti ${ }^{\mathrm{c}, 4}$, Surya Aditya Utama ${ }^{\mathrm{a}, 5}$ \\ ${ }^{a}$ Agribusiness Study Program, Faculty of Agriculture, Universitas Muhammadiyah Yogyakarta, Jl. Brawijaya, Kasihan, Bantul, Yogyakarta 55183 \\ Indonesia \\ ${ }^{b}$ Agrotechnology Study Program, Faculty of Agriculture, Universitas Muhammadiyah Yogyakarta, Jl. Brawijaya, Kasihan, Bantul, Yogyakarta 55183 \\ Indonesia \\ 'Law Science Study Program, Faculty of Law, Universitas Muhammadiyah Yogyakarta, Jl. Brawijaya, Kasihan, Bantul, Yogyakarta 55183 Indonesia \\ okiwijaya@umy.ac.id; ${ }^{2}$ lestari_rahayu@yahoo.com; 3,4,5 bhp@umy.ac.id; \\ * Corresponding author
}

\begin{tabular}{|c|c|}
\hline ARTICLE INFO & ABSTRACT \\
\hline $\begin{array}{l}\text { Article history } \\
\text { Received: 2021-05-01 } \\
\text { Revised: 2021-06-11 } \\
\text { Accepted: 2021-08-09 } \\
\text { Published: 2021-08-26 } \\
\text { Keywords } \\
\text { Agribusiness } \\
\text { Moringa agriculture } \\
\text { Village economic community }\end{array}$ & $\begin{array}{l}\text { This activity was motivated by the low economic status of the village community, which is located } \\
\text { far from the center of the district capital. On the other hand, there is potential for the development } \\
\text { of kelor (Moringa) in the village. This community service was carried out with the aim of improving } \\
\text { the community's economy through Moringa agribusiness in Pilangrejo Village, Nglipar District, } \\
\text { Gunung Kidul Regency. This activity was carried out in January-June 2020, in Danyangan Hamlet, } \\
\text { Pilangrejo Village, Nglipar District, Gunungkidul Regency. This activity was attended by the people } \\
\text { of Danyangan Hamlet, both men and women. The male participants were those who make a living } \\
\text { as farmers. While the female participants were housewives who do not have any permanent } \\
\text { livelihood. The number of primary participants were } 10 \text { people who were community leaders in } \\
\text { Pilangrejo Village. The implementation stages of activities include kelor planting and seedling, } \\
\text { training on post-harvest processing, and providing production tool. The implementation of this } \\
\text { activity is based on subsystems in agribusiness, namely the upstream (input) subsystem, on-farm } \\
\text { subsystem and downstream subsystem. The results of this activity can be said that the piloting of } \\
\text { Moringa agribusiness can be one solution that can be done in an effort to improve the economy of } \\
\text { the community in Danyangan Hamlet, Pilangrejo Village, Gunung Kidul Regency. The benefits that } \\
\text { can be obtained in this activity include the sale of Moringa powder and the use of Moringa as the } \\
\text { main menu in the community's food pattern. }\end{array}$ \\
\hline
\end{tabular}

Kata kunci

Agribisnis

Pertanian kelor

Ekonomi masyarakat desa
Rintisan agribisnis kelor sebagai upaya peningkatan ekonomi masyarakat desa. Kegiatan dilatar belakangi oleh rendahnya ekonomi masyarakat desa, yang terletak jauh dari pusat ibukota kabupaten. Di sisi lain, terdapat potensi pengembangan kelor di desa tersebut. Dari kondisi tersebut, dilakukan pengabdian masyarakat yang bertujuan melakukan upaya peningkatan ekonomi masyarakat melalui agribisnis kelor di Desa Pilangrejo, Kecamatan Nglipar, Kabupaten Gunung Kidul. Kegiatan ini dilaksanakan pada bulan Januari-Juni 2020, di Dusun Danyangan, Desa Pilangrejo, Kecamatan Nglipar, Kabupaten Gunungkidul. Kegiatan ini diikuti oleh masyarakat Dusun Danyangan, baik laki-laki maupun perempuan. Partisipan laki-laki adalah masyarakat yang bermata pencaharian sebagai petani. Sedangkan partisipan perempuan adalah ibu rumahtangga yang tidak memiliki mata pencaharian tetap. Jumlah partisipan inti berjumlah 10 orang yang merupakan tokoh masyarakat di Desa Pilangrejo. Tahap pelaksanaan kegiatan diantarannya meliputi penanaman dan pembibitan tanaman kelor, pelatihan pengolahan pascapanen, dan pemberian alat produksi. Pelaksanaan kegiatan ini berbasis pada subsistem pada agribisnis, yaitu subsistem hulu (input), subsistem on farm dan subsistem hilir. Dari kegiatan ini, dapat disimpulkan bahwa rintisan agribisnis kelor dapat menjadi salah satu solusi yang efektif dalam upaya peningkatan ekonomi masyarakat di Dusun Danyangan, Desa Pilangrejo, Kabupaten Gunung Kidul. Manfaat kegiatan yang dapat dirasakan dalam kegiatan ini diantaranya adalah hasil penjualan serbuk kelor dan pemanfaatan kelor sebagai menu utama dalam pola pangan masayarakat.

Copyright (C) 2021, Sabilah et al This is an open access article under the CC-BY-SA license

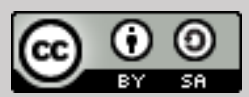

How to cite: Wijaya, O., Rahayu, L., Rokhim, N., Yusmiastuti, T., \& Utama, S. A. (2021). Piloting moringa agribusiness to improve villagers' economic community. Journal of Community Service and Empowerment, 2(3), 103-109. https://doi.org/10.22219/jcse.v2i3.16442 


\section{INTRODUCTION}

Pilangrejo Village, Nglipar District, Gunungkidul Regency is one village that is vulnerable to landslides. During 20122013, there were three villages in Nglipar District that suffered with landslides, they were Kedungpoh Village, Pilangrejo, and Pengkol. As a result of disaster, 37 houses were destroyed, three people injured, and one person got a serious injury with an estimated loss of IDR 236,500,000.00 (Badan Penanggulangan Bencana, 2012). In 2017, there was a large landslide disaster. This affected several houses were buried by the landslides so that 46 people were evacuated (Polda DIY, 2017). A similar case also occurred in 2018, Danyangan Hamlet, Pilangrejo Village suffered the landslides for eight meters long and six meters wide (Putri, 2017). Nurohmah (2017) states that apart from Pengkol Village and Kedungpoh Village, Pilangrejo Village, Nglipar Village, Gunung Kidul Regency, Yogyakarta Special Region was included in the zone category with a high level of danger.

The area of Pilangrejo Village is approximately $875 \mathrm{Ha}$, most of which are hilly areas. The use of some of the hilly areas is as dry land agriculture (Badan Pusat Statistik, 2020). Most of the crops cultivated are seasonal crops such as corn, rice, soybeans, and cassava. In addition to seasonal crops, residents also plant elephant grass for animal feed. Corn, rice, and soybeans are crops that the results are used for daily consumption and some are sold to meet other needs. On the other hand, the villagers of Pilangrejo depend on the agricultural sector for their livelihood. This condition encourages residents to maintain the planting pattern that has been done for years. On the other hand, the farming system carried out by residents has caused the land not able to store water during the rainy season. This is the cause of landslides in Pilangrejo Village, Nglipar District, Gunung Kidul Regency during the rainy season because there are no roots that hold back the contours of the soil (Badan Pusat Statistik, 2020; Badang Penanggulangan Bencana, 2012; Nurohmah, 2017; Putri, 2017).

The dry and hilly condition of the land in Pilangrejo Village should be planted with annual plants that have taproots so that they can function to hold the soil and minimize the possibility of landslides. However, due to economic conditions and food needs, residents in Pilangrejo Village, particularly in Danyangan Hamlet, replaced the annual corps with corn and cassava.

One alternative solution to this problem is to carry out nature conservation by planting annual plants that are able to withstand the contours of the soil while having an economic value. One of the annual plants that can be grown in the area is the Moringa plant. Moringa is an herbaceous plant that has a taproot. This plant is able to hold the contours of the soil and store water reserves so as to prevent landslides. In addition, Moringa plants have an economic value (K.F. Omotesho et al., 2013).

Based on the situation analysis and problems found in the targeted community, thus this community service aims to improve the economic gain of the community through Moringa agribusiness in Pilangrejo Village, Nglipar District, Gunung Kidul Regency.

\section{METHOD}

\section{Time and venue of the activity}

Moringa agribusiness pilot project activities serves as an effort to conserve the environment and improve the community's economy were carried out from January to June 2020 in Danyangan Hamlet, Pilangrejo Village, Bglipar District, Gunung Kidul Regency.

\section{Participants}

This activity was attended by the people of Danyangan Hamlet, both men and women. Male participants were people who make a living as farmers. While the female participants were the housewives who do not have a permanent livelihood. The primary participants were 10 people who played as pilot project group. However, the conservation activities carried out by this pilot group, in reality, were usually followed by public with an average of 20 participants per activity.

The people of Danyangan Hamlet in general make a living as farmers in rainfed and dry fields. Rainfed rice fields are usually planted with rice, corn, and secondary crops. Meanwhile, the field is used with cassava plants, or fruits for household consumption. In addition, most of the people in Danyangan Hamlet are categorized in the poor list, as their income from farming is relatively low (average net income from farming is IDR 1,500,000/harvest season) and is uncertain. People also plant secondary crops on sloping land which often causes landslides.

\section{Preparation}

Preparation in this community service were undertaken in three stages: 1) Observation; 2) Focus Group Discussion (FGD); and 3) Socialization. The observation was conducted to find out problems and potencies that exist in the location, so that the activities will be effectively done. Afterwards, the FGD was administered, to plan for the 
development of a participative village. To make the residents know about village development, the next stage was to conduct socialization.

\section{Implementation}

The implementation stages carried out in this activity includes: 1) moringa planting and seedling; 2) Training on postharvest processing; and 3) providing production tool. The implementation of this activity is based on subsystems in agribusiness, it is the upstream (input) subsystem, on-farm subsystem, and downstream subsystem.

\section{Monitoring and Sustainability Efforts}

The last stage in this community service was monitoring and compiling a roadmap for the sustainability of activities. It is expected that this activity can develop and bring an impact for the society and the environment.

\section{RESULTS AND DISCUSSION}

\section{Pre-activity observation}

The first stage done in this community service was activity observation. This observation was carried out to find out the problems and potencies that exist in the location, so that the activities can be effectively done. The results of observation show that the target location is a dry and hilly area. The hills in the location were reported to have frequent landslides. In addition, agriculture in the area relies on rainfed rice fields. The yard own by residents was used for fruit crops and livestock. In addition, during observation, many Moringa plants were found in the residents' yards. Almost all residents grow Moringa, but the plants had not been used optimally. Moreover, the residents did not know the efficacy of moringa plant.

\section{Focus group discussion}

After the observation had been done, the next stage was to do Focus Discussion Group (FGD) together with village community leaders. FGD was chosen as the method used to obtain in-depth information about the community and their expectations from this community service program. This method had also been proven effective by various qualitative studies (Paramita \& Kristiana, 2013), in particular in the field of conservation (O.Nyumba et al., 2018). The results of FGD was to determine the Moringa plant as a commodity to be developed in Pilangrejo Village. This was decided based on the problems and potencies of the village as the result of observation, as well as residents' expectation to improve community's economy based on local wisdom and environmental sustainability.

\section{Socialization on the activity plans}

The results of FGD were attended by several village community leaders, then socialized to the wider village community. This stage was carried out so that residents know the planned activities to be undertaken, thus, they could be interested in participating in this activity. Not only does it increase the community's motivation to be actively involved in the activities, but an overview of the benefits from the activity program is believed to be able to increase their commitment to carry out their role (Asah \& Blahna, 2013). The results of the socialization stage were the participation and enthusiasm of citizens in activities. Number of residents took part in this activity were 50 residents. This stage became the point in developing Moringa agribusiness in Danyangan Hamlet.

\section{Kelor (Moringa) planting and seedling}

After the socialization, the next activity was planting and seedling Moringa together with the community. This activity began with a symbolic tree planting by village officials, Muhammadiyah Branch Leaders, UMY student representatives, Babinsa, and Babinkamtibmas. In his remarks during the symbolic planting, a representative of village officials expressed his appreciation for piloting this activity. It was further stated that this activity was a community empowerment activity that had a holistic and integrative concept for the first time in Pilangrejo Village. The socialization activity was well documented in Figure 1. Considering the importance of community participation in conservation effort (Rathnayake, 2016), this socialization activity was a key to involving them.

Other than planting activities, this moringa agribusiness initiation activity was also done by moringa seedling. The seedling was carried out through seed or seeds. Seedling from seed was chosen on the grounds that the resistance of Moringa plants from seeds proved to be more durable. In addition, trees that grow from seed or seeds will have deep roots, forming deep taproots and fibers. The taproots will function to hold the soil and minimize the possibility of landslides (Adhitya et al., 2016; Santoso \& Parwata, 2018; Syarifuddin, 2017; Wasonowati et al., 2018). 


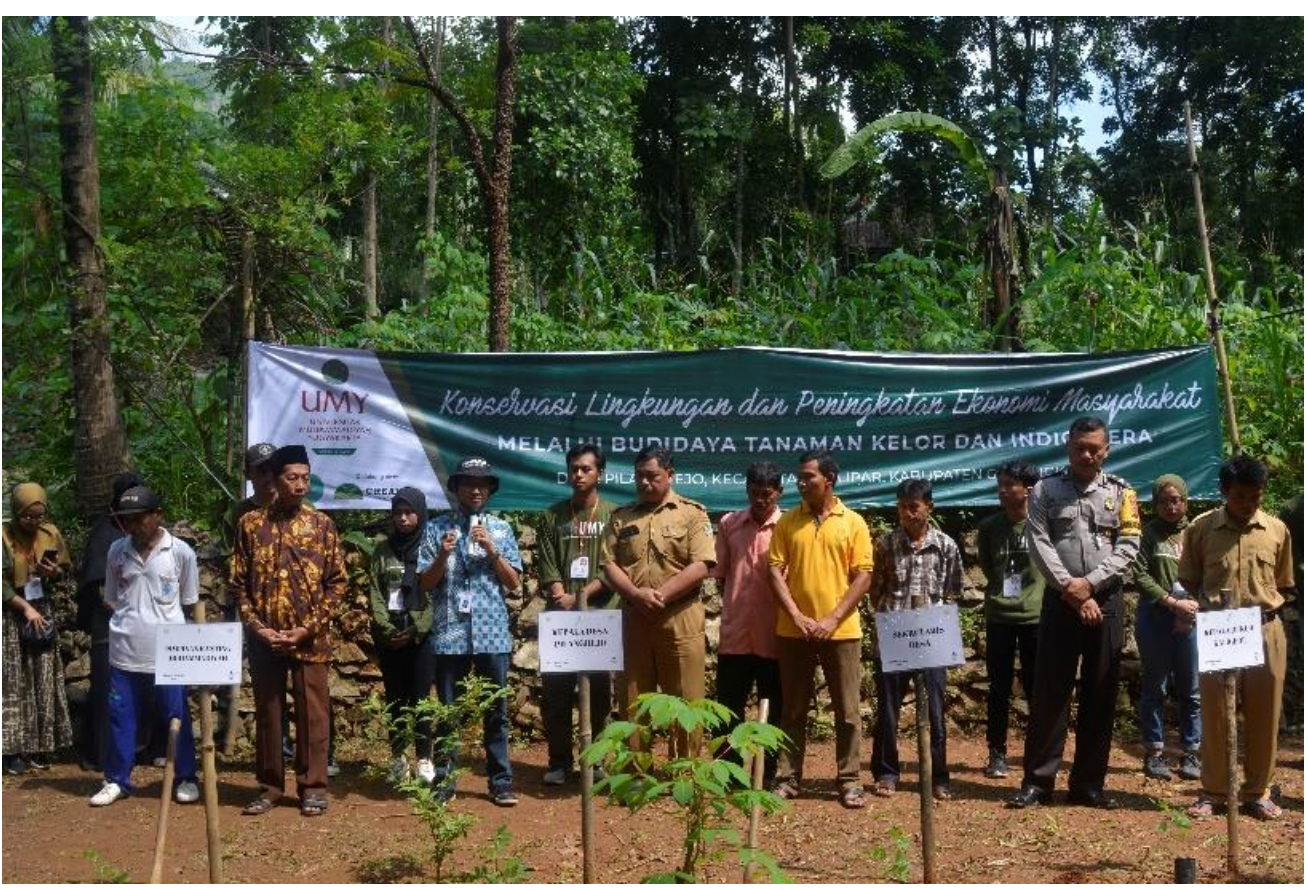

Figure 1. Symbolic Moringa planting by village stakeholders

\section{Training on Moringa leaf processing}

In the implementation phase, participants were taught how to process Moringa leaves for household food. Moringa leaf processing began with an explanation of how to dry Moringa leaves then how to use Moringa leaves and Moringa leaf powder. The community members were taught how to make cakes made from moringa, moringa tea mixed with palm sugar, moringa chips, and other various processed food. The training on how to process moringa leaves was conducted at Danyangan Hall as shown in Figure 2.

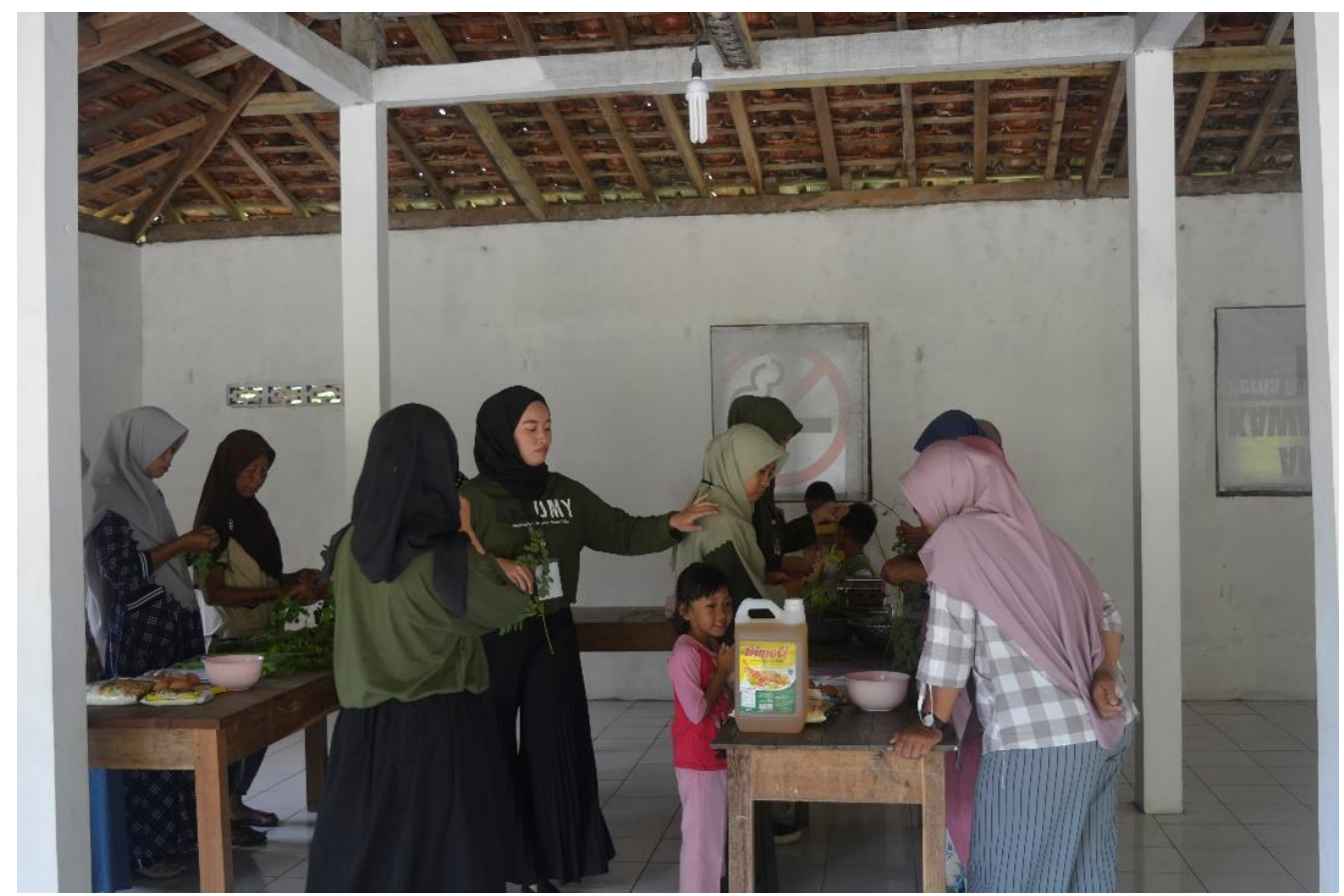

Figure 2. Training on Moringa leaves processing

In the future, it is expected that the community will be able to develop this Moringa leaf processing in more varied forms in order to increase the economic value. Theoretically, there have been many studies discussing about the health benefits of Moringa leaves for the various compounds contained in them (Arulselvan et al., 2016; Calderon-Montano et al., 2011; Leone et al., 2015). The benefits of processed Moringa leaves are not only for health, but also for improving environmental quality (Camacho et al., 2017; Rahman et al., 2014). By providing more information will also increase 
their participation in such economic and environmental conservation activities (Rasoolimanesh et al., 2017).

\section{Providing production tool}

Post-harvest processing production tool is an important part in the development of agribusiness in the village. One of the series of community service activities was to provide production tool in the form of moringa leaf flour machine as shown in Figure 3. With this tool, it is expected that residents can process moringa powder. To support this stage of activity, residents were introduced to how to use and function the tools. In addition, this stage was also equipped with a manual module composed by the project team. Through the manual module, the target group would easily understand the use of tools that could be learned independently when the project team were away (Wulandari et al., 2017).

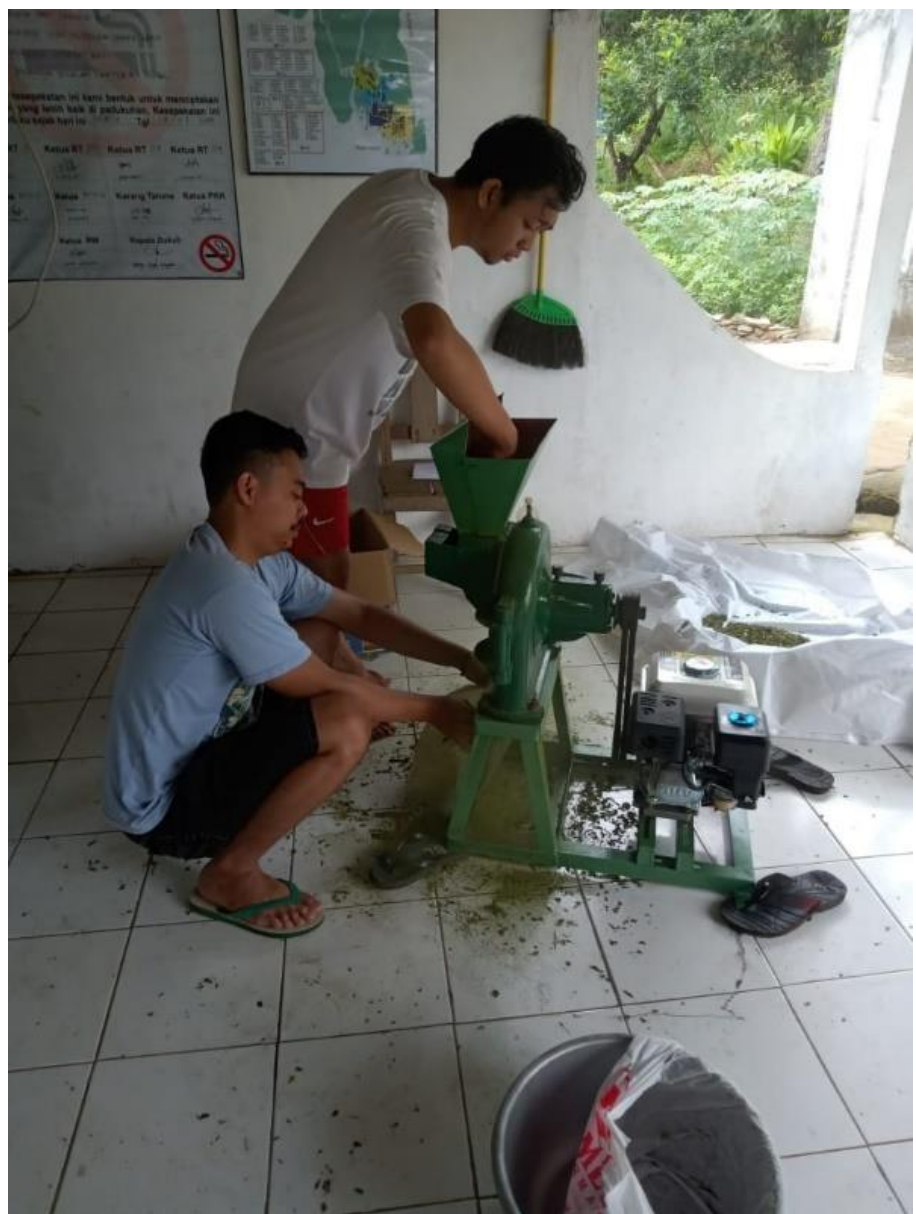

Figure 3. Process of recording the online teaching

\section{Discussion on development and sustainability plans}

This community service activity is still a piloting project of Moringa agribusiness in Pilangrejo Vilage, Nglipar District, Gunungkidul Regency. Therefore, there are still many shortcomings that must be addressed for better improvement in the future. The next development plan was discussed through regular community meetings led by the Head of Danyangan Hamlet and attended by 30 residents. The result of the discussion was the commitment of the residents to continue this activity, as well as to prepare a roadmap for the development of Moringa agribusiness-based village. These such discussions with residents was important to undertake, so that residents would not feel that this activity brought benefit for the project team only, but this is an effort made for village development (Sidik, 2015). Furthermore, long-term planning and a detailed explanation of the role and involvement of the community in this economic and environmental conservation effort will ensure the effectiveness of the program's sustainability (Rodríguez-izquierdo et al., 2010). 


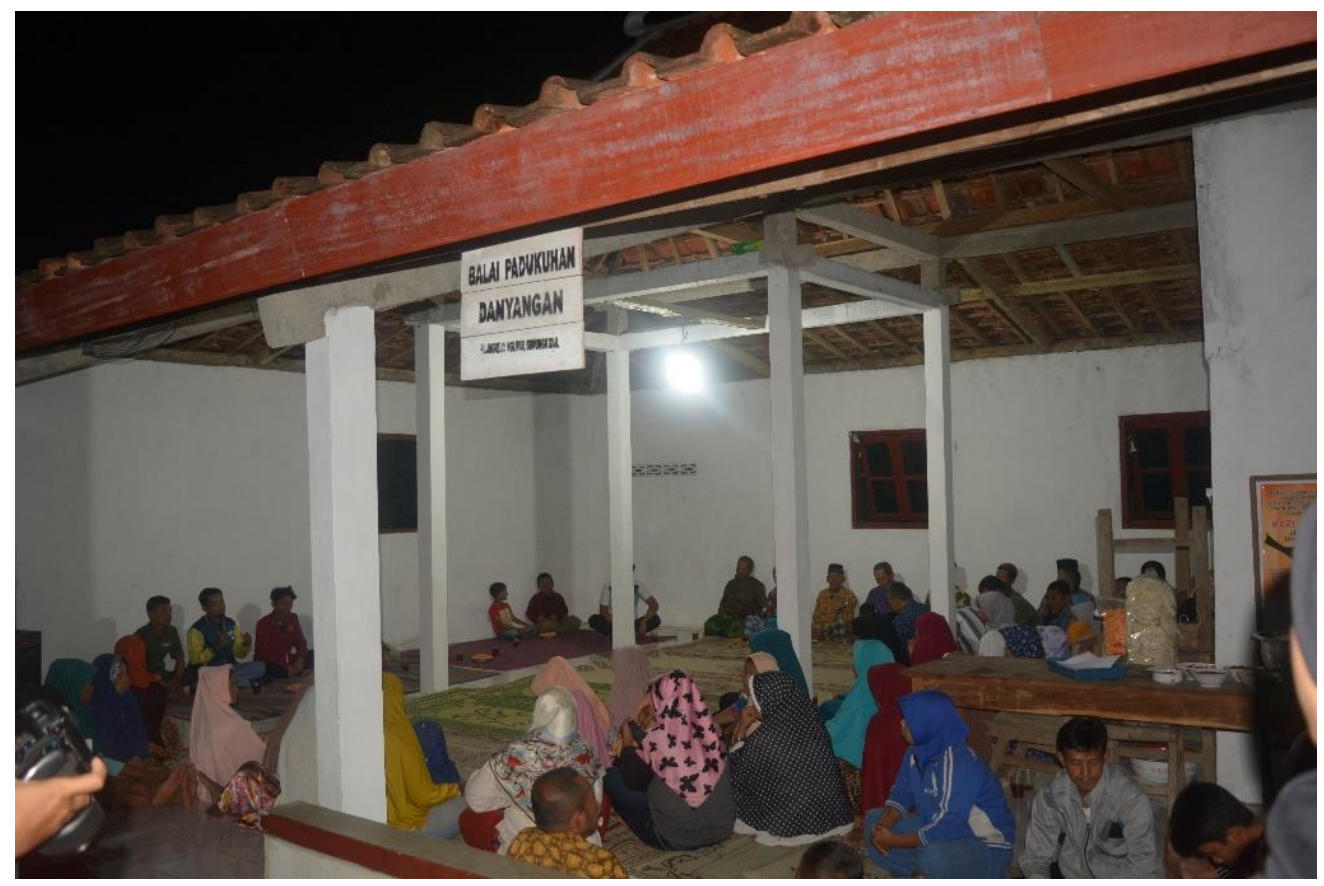

Figure 4. Discussion on development and sustainability

\section{CONCLUSION}

Mentoring activity on piloting moringa agribusiness can be an effective solution in efforts to improve the economy of the community in Danyangan Hamlet, Pilagrejo Village, Gunung Kidul Regency as well as to preserve the village environment.

\section{ACKNOWLEDGEMENT}

Our gratitude goes to the Rector and Vice Rector of the Universitas Muhammadiyah Yogyakarta and the Director of the Directorate of Research and Community Service, Universitas Muhammadiyah Yogyakarta, who have provided funding for this activity, as well as the partners so that this program can run smoothly.

\section{REFERENCES}

Adhitya, F., Rusdiana, O., \& Saleh, M. B. (2016). Penentuan Jenis Tumbuhan Lokasi dalam Upaya Mitigasi Longsor dan Teknik Budidayanya Pada Areal Rawan Longsor di KPH Lawu DS: Studi Kasus di RPH Cepoko. Jurnal Silvikultur Tropika, 8(1), 9-19.

Arulselvan, P., Fard, M. T., Tan, W. S., Gothai, S., Fakurazi, S., Norhaizan, M. E., \& Kumar, S. S. (2016). Role of antioxidants and natural products in inflammation. Oxidative Medicine and Cellular Longevity, 2016. https://doi.org/10.1155/2016/5276130

Asah, S. T., \& Blahna, D. J. (2013). Practical implications of understanding the influence of motivations on commitment to voluntary urban conservation stewardship. Conservation Biology, 27(4), 866-875.

https://doi.org/10.1111/cobi.12058

Badan Pusat Statistik. (2020). Kecamatan Nglipar Dalam Angka 2019.

Badang Penanggulangan Bencana. (2012). Rencana Kontijensi Menghadapi Ancaman Bencana Tanah Longsor di Kecamatan Gedangsari, Nglipar dan Ngawen, Gunungkidul.

Calderon-Montano, J. M., Burgos-Moron, E., Perez-Guerrero, C., \& Lopez-Lazaro, M. (2011). A review on the dietary flavonoid kaempferol. Mini-Reviews in Medicinal Chemistry, 11(4), 298-344. https://doi.org/10.2174/138955711795305335

Camacho, F. P., Sousa, V. S., Bergamasco, R., \& Ribau Teixeira, M. (2017). The use of Moringa oleifera as a natural coagulant in surface water treatment. Chemical Engineering Journal, 313, 226-237.

https://doi.org/10.1016/j.cej.2016.12.031

K.F. Omotesho, F.E. Sola-Ojo, T.R. Fayeye, \& R.O. Babatunde. (2013). The potential of Moringa tree for poverty alleviation and rural development: Review of evidences on usage and efficacy. International Journal of Development and Sustainability, 2(2), 799-813.

Leone, A., Spada, A., Battezzati, A., Schiraldi, A., Aristil, J., \& Bertoli, S. (2015). Cultivation, genetic, ethnopharmacology, 
phytochemistry and pharmacology of Moringa oleifera leaves: An overview. International Journal of Molecular Sciences, 16(6), 12791-12835. https://doi.org/10.3390/ijms160612791

Nurohmah, A. (2017). Kajian Resiko dan Mitigasi Bencana Longsor Lahan Di Kecamatan Nglipar, Kabupaten Gunung Kidul, Daerah Istimewa Yogyakarta. Jurnal Enersia Publika, I(2), 28-50.

O.Nyumba, T., Wilson, K., Derrick, C. J., \& Mukherjee, N. (2018). The use of focus group discussion methodology: Insights from two decades of application in conservation. Methods in Ecology and Evolution, 9(1), $20-32$. https://doi.org/10.1111/2041-210X.12860

Paramita, A., \& Kristiana, D. L. (2013). Teknik focus group discussion dalam penelitian kualitatif. Buletin Penelitian Sistem Kesehatan, 16(2), 117-127. www.enolsatoe.org/content/view/15/33/

Polda DIY. (2017). Hujan Deras Mengakibatkan Bencana Banjir dan Longsor Di Wilayah Nglipar.

Putri, A. (2017). Bencana Tanah Longsor Ancam Rumah Warga Danyangan. Sorot Gunungkidul.

Rahman, M. M., Hassan, M. H., Kalam, M. A., Atabani, A. E., Memon, L. A., \& Rahman, S. M. A. (2014). Performance and emission analysis of Jatropha curcas and Moringa oleifera methyl ester fuel blends in a multi-cylinder diesel engine. Journal of Cleaner Production, 65, 304-310. https://doi.org/10.1016/j.jclepro.2013.08.034

Rasoolimanesh, S. M., Jaafar, M., Ahmad, A. G., \& Barghi, R. (2017). Community participation in World Heritage Site conservation and tourism development. Tourism Management, 58, 142-153. https://doi.org/10.1016/j.tourman.2016.10.016

Rathnayake, R. M. W. (2016). "Turtle watching": A strategy for endangered marine turtle conservation through community participation in Sri Lanka. Ocean and Coastal Management, 119, 199-207. https://doi.org/10.1016/j.ocecoaman.2015.10.014

Rodríguez-izquierdo, E., Gavin, M. C., \& Macedo-bravo, M. O. (2010). Barriers and triggers to community participation across different stages of conservation management. Environmental Conservation, 37(3), 239-249. https://doi.org/10.1017/S0376892910000500

Santoso, B. B., \& Parwata, I. A. (2018). Biji dan teknologi benih kelor (Moringa oleifera Lam.). In Penerbit Arga Puji (1st ed., Vol. 7, Issue 2). Penerbit Arga Puji.

Sidik, F. (2015). Menggali Potensi Lokal Mewujudkan Kemandirian Desa. JKAP (Jurnal Kebijakan Dan Administrasi Publik), 19(2), 115. https://doi.org/10.22146/jkap.7962

Syarifuddin, N. A. (2017). Daun Kelor sebagai Pakan Ternak (1st ed., Issue April). UPT Unhas Press.

Wasonowati, C., Sulistyaningsih, E., Indradewa, D., \& Kurniasih, B. (2018). Pertumbuhan bibit kelor (Moringa oleifera lamk ) dari biji dan stek dengan interval pemberian air yang berbeda. Seminar Nasional Peran Keanekaragaman Hayati Untuk Mendukung Indonesia Sebagai Lumbung Pangan Dunia", 2(1), 175-181.

Wulandari, E., Ernah, \& Supyandi, D. (2017). Penguatan kemampuan manajerial petani melalui pelatihan dan pendampingan pencatatan finansial usaha tani di Kabupaten Cianjur. Dhamakarya: Jurnal Aplikasi Ipteks Untuk Masyarakat, 6(3), 189-192. 